\title{
2014 ASPA Teaching and Learning Conference
}

\author{
Kimberly A. Mealy, Director, Education, Professional and Diversity Programs, APSA
}

A PSA is looking forward to the 2014 APSA Teaching and Learning Conference (TLC). Registration opened in November 2013, including a new graduate student rate. The theme of the meeting is "Teaching Inclusively: Integrating Multiple Approaches into the Curriculum." The meeting will be held on February 7-9, 2014 in Philadelphia. This will be the 11th annual meeting of the teaching conference.

The 2014 Teaching and Learning Conference program committee has planned an interesting program that includes a keynote address, a new paper track on distance learning, and a pre-conference short course on massive open online courses, or MOOCs, led by John Ishiyama, University of North Texas. In addition, Cengage, a Benefactor sponsor, is generously sponsoring the Saturday lunch. During this time, they will be hosting a product demo of MindTap. The following themes/tracks return for the 2014 program: Curricular and Program Assessment; Civic Engagement; Teaching Research Methods; Internationalizing the Curriculum; Simulations and Role Play; Diversity, Inclusiveness, and Equality; Graduate Education: Teaching and Advising Graduate Students; Core Curriculum/General Education.

The research presented at this meeting is a resource to students, faculty, and the discipline more broadly. For example, each year the track discussions and major research findings that are presented at the APSA Teaching and Learning Conference are summarized and shared with the discipline in the July edition of $P S$ and online, thus providing a pedagogical resource. Scholars who participate in the TLC share their experiences with departmental colleagues and students, and, in many cases, go on to publish their work on teaching and learning in political science. Victor Asal of SUNY, University at Albany, and conference chair says this about the meeting:

The APSA Teaching and Learning Conference has expanded my knowledge base about different approaches to teaching and has expanded my network of colleagues who care about teaching. It has also greatly expanded the repertoire of many educators by exposing them to the innovative approaches of many of their colleagues related to assessment, simula- tions, teaching methodology, political theory, and other important components of teaching. My participation in the TLC has had a huge impact on my teaching and has given me a sounding board and brainstorming group that has become integral to my efforts to be a better and more effective teacher. The TLC has also made a very important contribution to empirically based pedagogy by bringing together people who are serious about research into effective teaching and giving them an incentive to do academic research on such questions.

The 2014 program committee includes Victor Asal, SUNY, University at Albany (Chair); Mark Johnson, Minnesota State Community and Technical College; Agnieszka Paczynska, George Mason University; Boris Ricks, California State University, Northridge; Cameron Thies, Arizona State University; and Sherri Wallace, University of Louisville.

We hope to see you at the meeting in February! For more information on the upcoming 2014 Teaching and Learning Conference, please visit http://www .apsanet.org/teachingconference.

\section{Report on the Meeting of the Political Science Members of the National Academy of Sciences}

\author{
David Laitin, Stanford University, and Gary King, Harvard University, rapporteurs
}

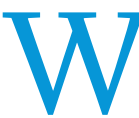

ith assistance of the APSA, the political science members of the National Academy of Sciences (NAS) held their standing meeting at the annual APSA convention in Chicago. The purposes of these meetings are two-fold: First, as required, to discuss ways that political science can fulfill the NAS mission in providing scientific evidence to address consequential public issues that come from queries posed by various agencies of government; and second, to increase the presence of political scientists in the Academy, where membership from our discipline is, in our view, much lower than political scientists' con- tributions to the scientific community, and does not adequately recognize the many political scientists who merit election. While we have made some progress toward this second goal, it is a complicated battle: 2,179 members and 437 foreign associates across scientific disciplines have been elected to and currently serve in the NAS, but only 21 are political scientists. ${ }^{1}$ Although the science-based mission of NAS does not seek to represent all of the highly pluralistic discipline of political science, far more research relying on methods that are recognized in the natural sciences is produced in our field than is presently represented in the NAS.
Although the NAS is an honorific society, its members have a responsibility to the US government. As its mission statement reads: "The National Academy of Sciences (NAS) is a private, non-profit society of distinguished scholars. Established by an Act of Congress, signed by President Abraham Lincoln in 1863 , the NAS is charged with providing independent, objective advice to the nation on matters related to science and technology. Scientists are elected by their peers to membership in the NAS for outstanding contributions to research. The NAS is committed to furthering science in America, and its members are active 
contributors to the international scientific community. Nearly 500 members of the NAS have won Nobel Prizes" (See http:// nasonline.org/about-nas/mission).

For the past century and a half, members have investigated and responded to questions posed by our national leaders as a form of service to the nation without financial recompense. As Ralph Cicerone, president of the NAS, never fails to relate to new members at the annual installation ceremony, while our advice is often solicited-its first report to the Lincoln administration addressed whether our country should adopt the metric system, and sent back a consensus "yes" answer-this advice is not always followed. Scientific objectivity is the goal of the Academy, not political advocacy.

The NAS has its own research infrastructure, with political scientist members performing three roles. ${ }^{2}$ First, political scientist members of the NAS serve as article editors for submissions to the NAS journal Proceedings of the National Academy of Sciences (PNAS), which has a vast readership across all scientific disciplines with an impressive citation count for its publications. The NAS also oversees a large staff of salaried professional researchers (usually not members of the NAS) who constitute the National Research Council (NRC). In the context of the NRC, political scientists in the NAS perform two further roles. First, they are often asked to serve as members or reviewers of committees that oversee research reports both in the natural sciences (where political scientists are asked to address questions of how scientific recommendations can be implemented effectively) and in the social sciences. Second, NAS members play a role in a branch of the NRC called DBASSE (the Division of Behavioral and Social Sciences and Education) that approves and oversees contracts with government agencies. The many arenas of research of
DBASSE can be accessed at http://sites. nationalacademies.org/DBASSE/index. htm. Presiding over DBASSE presently is political scientist Kenneth Prewitt. Scholars who are not NAS members also regularly participate as members of NAS committees, and we urge all political scientists to give serious consideration to these requests.

The discussion at this year's meeting of NAS-member political scientists at the APSA convention centered on how to effectively transmit the best social science knowledge to the government through the NRC. One issue facing the NRC in general and the DBASSE in particular is that by charter the NAS is not permitted to solicit contracts from government agencies, but merely to respond to their queries. In fact, after a query is posed, NRC staff can discuss how the proposal can be massaged in a way that will allow the scientific community to focus its attention on a specific problem. However, NRC staff are appropriately constrained on how much soliciting they can do, and therefore some excellent ideas for policy relevant research coming from both staff and from members do not always get funded. There are no easy answers here, but our discussion at this year's meeting sustained a conversation on how we can provide better research to relevant government agencies.

\section{NOTES}

1. The political scientists elected to membership in the NAS include Robert Axelrod, Larry Bartels, Philip Converse, Gary Cox, Robert Dahl, James Fearon, Richard Fenno, John Ferejohn, Morris Fiorina, Robert Keohane, Gary King, David Laitin, James March, David Mayhew, Johan Olsen, Robert Putnam, Kenneth Shepsle, Beth Simmons, Theda Skocpol, Sidney Verba, and Barry Weingast. Lin Ostrom played an active role in our activities until her recent death.

2. Beyond research, under the leadership of a committee chaired by Sidney Verba, the NAS is active in protecting human rights of scientists throughout the world.

\section{Coming in the NEXT ISSUE}

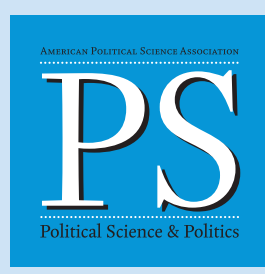

A preview of some of the articles in the April 2014 issue:

SYMPOSIUM

US PRESIDENTIAL ELECTION FORECASTING

Michael Lewis-Beck and

Mary Stegmaier, guest editors

\section{FEATURES}

Twitter Style: An Analysis of How House Candidates Used Twitter in their 2012 Campaigns Heather K. Evans, Victoria Cordova, and Savannah Sipole

Republicans in Name Only: Onomastic Political Identity Signals Robert Urbatsch

Reframing Polarization: Social Groups and "Culture Wars" Christopher Muste

\section{THE PROFESSION}

Encountering Resistance: Qualitative Insights from the Quantitative Sampling of Ex-Combatants Kate Christopher Roll

The Communication of Ideas across Subfields in Political Science Erin R. Graham, Charles R. Shipan, and Craig Volden

\section{THE TEACHER}

Teaching Political Theory at a Prison in South Texas William W. Sokoloff

A Sea of Riches: Teaching an Interdisciplinary Environmental Justice Course through Political Theory On-Campus and Online Teena Gabrielson and Kaitlyn Watts

The Strategy Project: Teaching Strategic Thinking through Crisis Simulation Michael Allen Hunzeker

ASSOCIATION NEWS

Completed Dissertations 